\title{
FINANCIAL CONTROL AS A MEANS OF COUNTERING ECONOMIC CORRUPTION IN UKRAINE
}

\author{
Oksana Kuzmenko' ${ }^{1}$, Oleksii Drozd ${ }^{2}$, Viktoriia Chorna ${ }^{3}$
}

\begin{abstract}
The aim of the article is to study the theoretical and legal principles of organization and implementation of financial control as a means of countering economic corruption in Ukraine. The subject of the study is financial control as a means of countering economic corruption in Ukraine. Methodology. The research is based on the use of general scientific and special scientific methods and techniques of scientific knowledge. The historical and legal method enabled to determine the preconditions for the origin of corruption as a negative social phenomenon. The comparative and legal method was used to compare doctrinal approaches to the differentiation of types of financial control. The system-structural method contributed to the perception and identification of the most negative impacts of corruption on the country's economy. The methods of grouping and classification were the basis for the author's original approach to the distinction between the types of the shadow economy, such as the informal economy, hidden economy, and criminal economy. The technical legal method enabled to investigate corruption in Ukraine, to identify its shortcomings, gaps, contradictions, and miscalculations, as well as to develop recommendations aimed at their elimination. The results of the study revealed that the ineffectiveness of state financial control in Ukraine contributes to the blossoming of corruption in Ukraine, due to the lack of legal regulation of its implementation and coordination in the activities of various controlling bodies, the weakness of the legal and methodological basis of their activities. They define law-making, law-executing, and law-enforcement activities, coordinate the functioning of financial and legal regulation. Practical implications. In the research, first, the key aspects of the genesis of financial control as a means of countering economic corruption in Ukraine are outlined; second, scientific approaches to their classification in the special literature are analysed and compared; third, the author's original differentiation is substantiated. Relevance/originality. The author's original approach to the differentiation of financial control as a means of countering economic corruption in Ukraine is the basis for developing the most promising directions for the improvement of domestic legislation in this area.
\end{abstract}

Key words: corruption, public administration, financing, shadow economy, financial control.

JEL Classification: P44, H83, 016

\section{Introduction}

Corruption is a phenomenon that affects the national security of any country. It depends on the effectiveness of public administration. Citizens and businesses are the most vulnerable to this phenomenon. The modern business is the flowering of oligarchic clans working in cooperation with state officials of the highest level. Therefore, the current economy of Ukraine is inefficient and corrupt, state enterprises continue to spend the budget to enrich their controlling stakes. Regulatory authorities decide on pricing according to the needs of dominant business interests. The land reform is blocked to provide benefits to agricultural magnates. Even the military budget is under the pressure via corruption procurement methods. Banking reform is accompanied by expropriation of public funds by private owners

Corresponding author:

${ }^{1}$ National Academy of Internal Affairs, Ukraine.

${ }^{2}$ National Academy of Internal Affairs, Ukraine.

${ }^{3}$ National Academy of Internal Affairs, Ukraine. of banks. Small and medium-sized businesses suffer from internal corruption, which is based on abuse of authority, dishonest actions in exchange for money or personal benefits of company employees. Unfortunately, it is extremely widespread in the Ukrainian business environment causing these companies significant financial and reputational losses. This phenomenon affects the business climate in Ukraine not less than corruption.

\section{Literature review}

In their works, a number of authors interrogated certain aspects of this problem, such as T. Vasilevska, V. Galunko, O. Yeshchuk, O. Onyshchuk, S. Rivchachenko, O. TokarOstapenko. In general, the anti-corruption was studied by V. Alexandrov, V. Kolpakov, M. Melnyk, R. Melnyk, 
I. Nurullaiev, S. Rogulskyi, S. Stetsenko, V. Tilchyk, O. Tkachenko, R. Tuchak, I. Yatskiv, and others.

Therefore, the study of the doctrinal approaches to the concept and content of financial control as a means of countering economic corruption in Ukraine, which is the aim of this article, becomes relevant. For its successful achievement, the following tasks should be solved: first, to outline the key problems of the development of corruption in Ukraine; second, to analyse the perspectives in the special literature regarding the types of financial control; third, to propose the author's original approach to the definition of financial control as a means of countering economic corruption in Ukraine.

\section{The main material}

Academician of the National Academy of Sciences V.M. Heiets argues that the causes of the collapse of the Ukrainian economy are the criminalization of relations between state institutions and business, the most profitable sectors of the Ukrainian economy, distributed between the clans, and the "separation" of Ukraine from the world economy (Heiets, 2009).

Therefore, the diversified Ukrainian corruption in public administration deprives the individual anticorruption countering of its expediency and leads to an "unfavourable" equilibrium characterized by a constant level of corruption, low total investments, and weak economic growth of the state.

The most negative impacts of corruption on the country's economy include:

1. Expanding the shadow economy. This leads to a reduction in tax revenues to the budget. As a result, the state loses financial levers of economic management; social problems are exacerbated due to budget defaults.

2. Competitive mechanisms of the market are violated because often the winner is not the one who is competitive but the one who has been illegally able to gain advantages. This leads to a decrease in market efficiency and brings discredit on the ideas of market competition.

3. The emergence of effective private owners decelerates, primarily due to violations during privatization, as well as artificial bankruptcies, usually associated with bribery of officials.

4. Budget funds are used inefficiently, in particular, when distributing government orders and benefits. This complicates further budget problems of the country.

5. Prices increase due to "corruption costs". As a result, consumers suffer.

6. Agents show disbelief in the ability of the authorities to establish, control, and adhere to honest rules of the market game.

7. The investment climate degrades leading to unsolved problems of overcoming the decline of production, renovation of fixed assets.
8. Corruption is expanding in non-governmental organizations (firms, enterprises, and public organizations). This leads to a decrease in the efficiency of their work, and accordingly, in the effectiveness of the economy of the country as a whole (Blank, Batrakova, 2016).

Corruption leads to the emergence of a shadow economy, based on the economic activity of subjects seeking to conceal their wealth, avoid paying taxes, and hide the movement of their assets.

The main causes of a shadow economy are the imperfection of Ukrainian legislation contributing to tax pressure, confusion in tax administration, the lack or absence of assistance in obtaining tax benefits, lobbying interests of business groups close to the authorities.

The shadow economy is manifested through the informal economy, hidden economy, and criminal economy.

These types of shadow economy should be considered in detail.

Informal economy is a diverse activity of subjects that is currently not controlled by the state, is not subject to taxes due to its mass scale, growth of information technologies, lack of citizen awareness, aimed at using the services provided at home (tutoring, construction works, sale of products from household plots in the spontaneous markets).

The hidden economy is a legitimate economic activity, which, along with general-authorized actions, uses various manipulations to generate additional profits due to imperfect legislation.

The criminal economy is various illegal economic activities, not allowed by the state. It is characterized by illegal income and non-payment of taxes.

According to the World Bank's Doing Business data, in case of a positive countering corruption and the withdrawal of the Ukrainian economy from the shadow, Ukraine will receive 6 billion hryvnias, which is about $6 \%$ of Ukraine's GDP, the deficit of the whole system of finances is about $8-9 \%$ by the results of this year (Patrikieieva).

Nowadays, the main corrupt schemes that lead to economic corruption occur:

in public procurement;

in using budget funds (during the distribution of state orders and privileges);

in the implementation of international and state programs;

in providing administrative services.

Therefore, the spread of corruption and its impact on market relations in the country lead to a violation of the competitive market, because often the winner is not the one who is competitive but the one who is illegally able to benefit. This causes a reduction in the market efficiency and discredits the ideas of market competition as a whole; besides in public money, the state suffers significant financial losses because of violations of competitive principles, such as overestimation of 
the value of government contracts and poor supply of contracts concluded as a result of corruption. Indirectly, the state loses over the lack of interest from representatives of international business to enter the state procurement market considering the current situation in Ukraine. Therefore, competition is reducing, moreover, market prices are being overestimated, new advanced technologies are not applied, and Ukraine's integration into the European economy is decelerating. Therefore, according to the Anti-Corruption Centre, in one year, Ukraine spends about 300 billion UAH per year on public procurements; more than two billion hryvnias were returned to the state budget by preventing certain corruption schemes in 2016 (IT zadlia reform).

Another corruption manifestation is an inefficient use of budget funds; in particular, in the distribution of state orders and benefits that further complicates budget problems of the country. In addition, when government orders are executed by organizations "recommended" by an official, who has received remuneration from such an organization, poor execution of such orders is of a high probability, which is followed by "reimbursement" at the expense of public funds.

Moreover, if one body is empowered to provide administrative services combined with control and supervisory functions, corruption risks arise because of the uncertainty of the assigned authorities and appointment of the appropriate body, reducing the objectivity of examination and revision of administrative cases. Obviously, the managerial (service) type of activity and the inspection type of activity use different methods and forms. Moreover, in case of a violation of the rules for issuing a certain permit (license), the body that inspects the activities of a private person, first, will not be interested in identifying own shortcomings, and second, it finds itself outside of the external control, which also gives rise to corrupt practices. Nowadays in Ukraine, there are more than 70 supervisory bodies. At the same time, the total funds actually charged to the budget in 2017 were at $9 \%$ of the total amount of imposed financial sanctions. It should be noted that one visit of a representative of the controlling body to the company costs the state 11.6 thousand UAH (\$350), and the average amount of proceeds from fines per one inspection is $180 \mathrm{UAH}(\$ 6)$.

Shadow revenues lead to an unfair distribution of national profits, as corrupt officials accumulating for themselves a significant part of the financial resources of the state direct them to finance the import of luxury goods, as well as to the currency market increasing the pressure on the country's balance of payments. In addition, for the sake of their security and secrecy, corruption profits are usually offshored depriving the domestic economy of financial resources necessary to socio-economic growth (Bereza).

The analysis of the abovementioned aspects of corrupt practices reveals that their main negative impact on the financial system of the country comes from reducing tax revenues and losses of public funds in the form of losses, or in the form of excessive expenditures for the state.

The state tries to counter economic corruption mainly by the introduction of financial control over persons performing functions of the state and local self-government bodies. Financial control is aimed at identifying the illegal enrichment of the indicated subjects, disclosing the inconsistency of the dynamics of the actual declaration of property (movable and immovable) with official incomes, which should be the basis for bringing a person to criminal liability (according to Transparency International, last year 115 Ukrainian officials declared 375 offshore companies in 41 countries).

The illegal enrichment of officials, associated with their position, the use of official functions for obtaining various preferences and abundance for themselves, relatives or third parties, is especially dangerous. It should be noted that these persons could not act outside an official economy since the latter is a prerequisite for the establishment of corruption relations, because to abuse powers, a person should occupy a certain position in governmental bodies and be empowered. In addition, the official economic subsystem is a cover for the shadow economy, because for enrichment corruptors use their powers and evade legal liability.

Persons, authorized to perform state or local government functions, are obliged to file a declaration by filling in on the official website of the National Agency for Prevention of Corruption. The Law of Ukraine "On Prevention of Corruption" provides for to examine declarations in detail within ninety days from the date of submission of a declaration, including clarifying the validity of the declared information, the accuracy of the assessment of the declared assets, testing for a conflict of interest and signs of illegal enrichment. For example, according to the Ministry of Justice of Ukraine, authorized departments (persons) of territorial subdivisions and organizations, institutions and enterprises (within its supervision) submitted declarations in the number of 45,517 , of which: 14668 by public officials (of which 5824 persons discharged or retired in 2017), 20773 by rank and file and command staff of the State criminal-executive service, 4252 by officials of legal entities of public law. Therefore, the requirements to submit electronic declarations were fully implemented by 41798 persons, violated by 463 persons, and not executed by 3256 persons. To be precise, for the failure to submit declarations, 3719 people should be brought to administrative responsibility, in fact, in 2017, 4436 people were brought to administrative responsibility for all corruption-related offenses. Therefore, the inevitability of punishment for corrupt practices is not observed and the principle of punishment for the committed offences is not followed (Zahalni pokaznyky stanu zdiysnennia sudochynstva v Ukraini za 2017 rik). 
The legislation provides for that the declarations of officials in responsible positions, subjects occupying positions of high corruption risks, the list of which is approved by the National Agency, are subject to obligatory complete examination. Declarations filed by other entities of the declaration are subject to obligatory complete examination in case of inconsistencies in them detected by logical and arithmetic control.

A novelty of the legislation is monitoring the way of life of the subjects of the declaration. The reporting subjects' lifestyle monitoring is carried out selectively by the National Agency to conform their standard of living to the property and income obtained by them and their family members according to the declaration of the person authorized to perform the functions of the state or local self-government.

Such a monitoring is based on information from individuals and legal entities, as well as from the media and other open sources of information, which contain evidence on the inconsistency of living standards of the reporting subjects with their assets and income in the declaration.

In case of revealing signs of corruption offense or corruption-related offense based on monitoring, the National Agency informs bodies specifically authorized for countering corruption.

The latest legislative innovation on financial control of officials obliges a subject of the declaration to notify the National Agency for the Prevention of Corruption on any significant change in his/her property status, such as receipt of income, acquisition of property exceeding 50 minimum wages established on January 1 of the corresponding year. Within ten days from the date of receipt of income or the acquisition of property, the subject of the declaration must notify the National Agency in writing. The information shall be entered into the Unified State Register of Declarations of persons authorized to perform functions of the state or local self-government and shall be made public on the official website of the National Agency.

Nowadays, to ensure the timeliness and validity of declarations, the legal responsibility is established for the following practices:

1) untimely submission of the declaration without valid reasons;

2) failure to notify or untimely notification of the opening of a currency account in a non-resident bank;

3) failure to notify or untimely notification of substantial changes in the property status;

4) submission of deliberately false information in the declaration, if such information differs from the reliable in total from 100 to 250 living wage for able-bodied persons;

5) submission of deliberately false information in the declaration if such information differs from reliable in total more than 250 living wage for able-bodied persons;
6) deliberate failure to submit a declaration (Article 366-1 of the Criminal Code of Ukraine).

It should be noted that characterization of failure to notify or untimely notification of substantial changes in the property status by persons authorized to perform functions of the state or local selfgovernment has gaps concerning the unclear definition of these concepts. Therefore, failure to submit a declaration differs from the late submission only by the fact that at the time of the proceedings the person has not yet filed such a declaration. Regimes of liability (criminal and administrative) for failure to submit and for late submission of the declaration are socially conditioned because a deliberate failure to submit a declaration means that the person actually refuses to submit such a declaration. In this case, financial control based on a declaration is impossible, which requires additional and significant efforts of the controlling bodies to establish the actual property status of the subject of the declaration. Instead, the late submission of the declaration does not mean the loss of the opportunity to control, however, due to the delay in submitting the declaration, such a control cannot be carried out in a timely manner, which violates its order and enables concealment of assets by an official. The above also demonstrates the difference in the danger of the offences under consideration (Mikhailichenko, 2017).

In addition, Ukrainian legislation imposes an obligation to conduct financial monitoring of financial transactions equal to or exceeding 150 thousand hryvnias in total. However, such a link is not appropriate since declaring expenditures is meant to identify those employees whose expenditures do not correspond to their income. Therefore, the wage-linked principle would be advisable.

\section{Conclusion}

Therefore, to improve the Ukrainian legislation and make it closer to world practice, appropriate changes should be made; and accordingly, the declaration of false information should be criminalized to tighten crime prevention in official and professional activities related to the public services; moreover, only the introduction of the most repressive influence on the actions of the relevant nature may turn filling and submission of assets declarations by public officials into the real mechanism for combating corruption.

Therefore, the ineffectiveness of state financial control in Ukraine as a whole is caused by the lack of legal regulation of its implementation and coordination in the activities of various controlling bodies, the weakness of the legal and methodological basis of their activities. That is why nowadays, Ukraine as a legal state should create a legal framework for financial control involving society. 


\section{References:}

Heiets, V. (2009). Makroekonomichna otsinka hroshovo-kredytnoi i valyutno-kursovoi polityky Ukrainy do i pid chas finansovoi kryzy [Macroeconomic assessment of monetary and monetary and exchange rate policy of Ukraine before and during the financial crisis]. Ekonomika Ukrainy [Ukraine economy], 2, 5-24. (in Ukrainian)

Blank, M. E., Batrakova, T. I. (2016). Vplyv koruptsii na ekonomiku Ukrainy [The influence of corruption on the economy of Ukraine]. Naukovyi visnyk Uzhhorodskoho natsionalnoho universytetu [Scientific Bulletin of Uzhgorod National University], 7, 25-28. (in Ukrainian)

Patrikieieva, N. Ukraina vyhrala vid borotby z koruptsiieiu 6 miliardiv dolariv - analityky [Ukraine has won $\$ 6$ billion out of countering corruption - analysts]. Retrieved from: https://www.radiosvoboda.org/a/29359933. html (in Ukrainian)

IT zadlia reform [IT for reforms]. Retrieved from: http://it4reform.org/2015/02/23/top-3/

Bereza, O. D. Koruptsiia u sferi derzhavnoho upravlinnia yak strymuiuchyi faktor sotsialno-ekonomichnykh reform [Corruption in public administration as a restraining factor in socio-economic reforms]. Retrieved from: http://academy.gov.ua/ej/ej19/PDF/22.pdf (in Ukrainian)

Zahalni pokaznyky stanu zdiysnennia sudochynstva v Ukraini za 2017 rik [General indicators of justice in Ukraine in 2017]. Statistical collection. Retrieved from: http://www.viaduk.net/clients/vsu/vsu.nsf/(documents)/ F137F88C3D532965C22581D4003A6158 (in Ukrainian)

Mikhailichenko, D. H. (2017). Vzaiemodiia elementiv deliktnoho zakonodavstva dlia zabezpechennia antykoruptsiinoho finansovoho kontroliu [Interaction of elements of tort law to provide anti-corruption financial control]. Sudova ta slidcha praktykav Ukraini [Judicial and Investigative Practice in Ukraine], 4, 24-37. (in Ukrainian) 